\title{
RADICALISM, JIHAD AND TERROR
}

\author{
Yuminah Rahmatullah \\ UIN Syarif Hidayatullah Jakarta \\ Email:yuminah@uinjkt.ac.id
}

\begin{abstract}
As an issue of complexity, radicalism does not stand alone. It has a political and ideological basis. Like an ideology that continues to bind, radicalism takes the path of religion to be able to justify all actions of anarchy. The case of today's Islam as being synonymous with radicalism is apart of the complexcity of the issue. Religious radicalism is a prevalent phenomenon in the history religions. Radicalism is closely related to fundamentalism, which is marked by the return of society to the fundamentals of religion. Fundamentalism is a kind of ideology that makes religion the principle of life by society and individuals. Fundamentalism usually comes along with radicalism and violence when the freedom to return to religion is hindered by social and political circumstances surrounding the society. Islam recognizes jihad that is in some cases misunderstood. Jihad is different from radicalism and its derivatives of terrorism. Radicalism and terrorism tend to be destructive, uncompromising and closely related to violent behavior in the name of religion. Meanwhile jihad is a form of the totality of a Muslim's devotion to God, which is concerned not only with self-defense efforts, but a battle that has a theological legitimacy in which the martyrs are promised by God with various virtues and advantages. The association of jihad with terrorism today cannot be justified due to the fact that jihad in the sense of war (Qitâl) involves elements of violence that can be categorized as terrorism. It is the case that the use of violence in the name of religion in contemporary times is, in fact, due to political factors, which then seeks its legitimacy in religious teachings.
\end{abstract}

Keywords: radicalism; jihad; terrorism; tolerance; politics; legitimacy of religion

\section{INTRODUCTION}

Radicalism, anarchism and/or religious violence tend to be on the rise or at least appear and disappear in recent years. Religious radicalism that gives rise to religious conflict and social violence has spread not only among religions, such as Islam versus Christianity, but also between religions, such as among Islam or Christianity. ${ }^{1}$ Facing such phenomenon, the public figures

${ }^{1}$ Azyumardi Azra, The Roots of Religious Radicalism, The Role of State Apparatus, Religious Leaders and Teachers for Religious Harmony, Paper presented at Discussion 'Reinforcing Tolerance Through Schools’ at the Habibie Center, Hotel Aston Bogor, 14 May 2011 
and the public in Indonesia consider the continues increase in intolerance and radicalism in the inter-religious environment even with the State can clearly threaten the unity of the nation and the existence of the nation state of Indonesia. The rise of religious radicalism has its roots in the reality of various interpretations, understandings, schools of thought, denominations and even sects within a particular religion. In the case of Islam, religious radicalism is derived from literal, piecemeal and ad hoc religious understanding of the verses of the Qur'an. Such understanding can hardly provide space for adaptation and compromise with other moderate Muslim groups.

This kind of Islamic group has actually emerged since the time of the Fourth Khulafa 'al-Rashid' Ali ibn Abi Talib in the form of a very radical Khawarij and committed a lot of murders against Muslim leaders whom they declared as infidel.'2 Religious radicalism has become a mainstream and a global issue. The emergence of political issues concerning Islamic radicalism is a new challenge for Muslims to answer. The issue of Islamic radicalism has long been on the surface of international discourse. Islamic radicalism as a historicalsociological phenomenon is a much-discussed issue in political discourse and global civilization due to media power that has great potential in creating the perception of the world community. Many labels have been given by Western Europeans and the United States to refer to this radical Islamic movement, ranging from militant groups, extremists, militants, right-wing Islam, fundamentalism, to terrorism. Even the Western countries after the collapse of communist ideology (post cold war) see Islam as a frightening civilization movement.

Religious radicalism is actually a phenomenon that usually appears in various religions. Radicalism is closely related to fundamentalism, which is marked by the return of society to the fundamentals of religion. Fundamentalism is a kind of ideology that makes religion a lifeline to society and individuals. Usually fundamentalism comes along with radicalism and violence when the freedom to return to religion is hindered by social and political situation surrounding the society.

Radicalism means belief in radical ideas and principles ${ }^{3}$ and is a radical

${ }^{2}$ Azyumardi Azra, The Roots of Religious Radicalism, The Role of State Apparatus, Religious Leaders and Teachers for Religious Harmony, Paper presented at Discussion 'Reinforcing Tolerance Through Schools' at the Habibie Center, Hotel Aston, Bogor, 14 May 2011, p.3

${ }^{3}$ As Hornby, Oxford Advanced Learner Dictionary of Current English, (Walton: Oxford University Press. 1989, p.1032. Radicalism in the sense of language means a view or school of thought that wants change or social and political renewal by means of violence or drastic. However, in another sense, the essence of radicalism is the concept of mental attitude in carrying change. While radicalism is in another sense the essence of that change 
movement or ideology of the political order; doctrine or movement that demands social and political change in a country in a strict way. ${ }^{4}$ Azyumardi Azra (2015) mentions that radicalism is an ideology which believes that comprehensive change can only be done in a radical way, not in an evolutionary and peaceful way. ${ }^{5}$ Marx Juergensmeyer (as quoted by Muhammad Harfin Zuhdi, 2010) argues that radicalism can be understood as an attitude or position that craves changes to the status quo with total destruction, and replaces it with something new and different. ${ }^{6}$ Nurcholis Madjid (1995) explains that Islam is a religion of peace that teaches and seeks peace. ${ }^{7}$ And Harun Nasution (1995) mentions that radicalism is a movement that is oldfashioned and often uses violence in teaching their beliefs. ${ }^{8}$

Meanwhile, Yusuf al-Qaradawi, gives the term radicalism with the term alTatarruf ad-Din or in other words, is to practice the teachings of religion unnecessarily, or to practice religious teachings by taking a tarf or peripheral position, far from the substance of Islamic teachings, that is moderate teaching in the middle. Usually this peripheral position is heavy or over-emphasized and excessive, which is not reasonable. Further al-Qaradawi said the position of religious practices like this at least contain three weaknesses, namely: first, it is not favored by human nature; second, it cannot live long, and third, it is very vulnerable to violate the rights of others. ${ }^{9}$

The term Islamic radicalism comes from the Western press to point to the hard-line Islamic movement (extreme, fundamentalist, militant). The term radicalism is a code that is sometimes unconscious and sometimes explicit for Islam. ${ }^{10}$ The problem in the West and America is not Islam itself but the violent practices perpetrated by a group of Muslim communities in the process of establishing the identity of the group. ${ }^{11}$ For examples, there was a tends to use violence. In the Arabic term the term radicalism with the actions of extremism (at-tatharuf al-diniy), excessive (ghuluw), narrow-minded (dhayyiq), rigid (tanathu), and hard (tasyadud).

${ }^{4}$ Eka Yani Arfina, Kamus Lengkap Bahasa Indonesia Dilengkapi Dengan EYD dan Singkatan Umum, (Surabaya : Tiga Dua. tt )

${ }^{5}$ Azyumardi Azra, Waspadai Paham Radikal, Kompas, 7 April 2015, Guru Besar UIN Syarif Hidayatullah Jakarta; Anggota Komisi Kebudayaan AIPI and Council on Faith, World Economic Forum, Davos

${ }^{6}$ Muhammad Harfin Zuhdi, "Fundamentalisme dan Upaya Deradikalisasi Ayat al Qur'an dan Hadis", in Jurnal Religia, Vol. 13, No. 1, April 2010, 83

${ }^{7}$ Nurcholish Madjid. (1995). Pintu-Pintu Menuju Tuhan. (Jakarta: Paramadina), p. 260

${ }^{8}$ Harun.Nasution, (1995). Islam Rasional. (Bandung: Mizan), p.260

${ }^{9}$ Lihat Yusuf al-Qardhawi, al-Sahwah al-Islamiyyah: Baina al-Juhad wa al-Tatarruf (Kairo: Bank at-Taqwa, 2001), p. 23-29.

${ }^{10}$ Ahmed, Akbar S. (1993). Posmodernisme, Bahaya dan Harapan bagi Islam. Terjemah M. Sirozi. Mizan: Bandung.p.30

${ }^{11}$ Nurcholish Madjid. (1995). Pintu-Pintu Menuju Tuhan. Jakarta: Paramadina.h, 270 
case of disappearance of 12 students of Muhammadiyah University of Malang who have been recruited into the network of Islamic State of Indonesia (NII). This latest development indicates that although the National Police in this case, Densus 88, has succeeded in paralyzing most of the radical network of al-Jama'ah al-Islamiyah (JI) which carried out numerous bombings including suicide bombings especially since the First Bali Bomb was clearly a radical group and a cell that remains at large. Even it forms new cells that tend to move independently in one way or another, and are still related to each other ${ }^{12}$.

Some of the above notes illustrate how religion is not only an ideology, but also a motivation and an organizational structure for the perpetrators of violence. This radical belief in the name of religion is what is often manifested in terrorist acts. Madeline Albright, in 1998 for example, listed the world's 30 most dangerous terrorist organizations, and over half of them were religious groups. In fact according to RAND-st Andrews in the Chronology of International Terrorism, the number of denominations increased from 16 to 49 terrorist groups identified in 1994, then the following year it became 26 of the 56 registered groups. Therefore, it is no exaggeration for Warren Christopher to suggest that religious terrorist acts (other than ethnic identity) constitute one of the most important security challenges to be faced in relation to the rise of the cold war. ${ }^{13}$ Thus religious radicalism is a philosophy that refers to the beliefs of a particular group that wish to make changes to the religious values considered contrary to their belief. This is carried out by tearing down existing systems and structures to the roots quickly over subjective considerations.

\section{THE RISE OF RADICALISM MOVEMENT}

The movement of radicalism is not really a movement that merely appears, but mostly related to some issues driving the emergence of the radical movement. Internal factor from within Muslims itself is found as an important point. This factor occurs because of deviation of religious norms. Secular life in the life of society encourages them to return to the Islamic fundamentalism. This attitude is supported by a totalistic ( $k a f f a h)$ and formalistic religious view that is rigid in understanding religious texts. The study of religion is viewed only from one direction, textual, not viewed from other factors, so the actions they take must refer to the Prophet's behavior literally. External factors outside Muslims

${ }^{12}$ Azyumardi Azra, Akar Radikalisme Keagamaan, peran Aparat Negara, Pemimpin Agama dan Guru untuk Kerukunan Umat Beragama, Makalah disampaikan pada Diskusi'Memperkuat Toleransi Melalui Sekolah'The Habibie Center, Hotel Aston, Bogor, Bogor, 14 Mei 2011, p.3

${ }^{13}$ Mark Jurgensmever, Teror in The Mind of God: The Global Rise of Religion Violence, (trj), M.Sadat Ismail, Jakarta: Nizham Press 2002), p. 3-4 
is also found as another important point, whether committed by the regime of power or hegemony from the West that does not support the implementation of Islamic Shariah in the aspects of life. ${ }^{14}$

Azyumardi Azra (2012) argues that, in the Islamic circles, religious radicalism comes from a literal, piecemeal religious understanding of the verses of the Qur'an. Such understanding barely leaves room for accommodation and compromise with other groups of Muslims, resulting in social conflict and intra-religious and inter-religious violence; also even among religious people with the state. The continuation of intra- and inter-religious social conflicts in this reform period, again, is also due to a variety of complex factors such as those related to the euphoria of freedom, where each person or group feels able to express their freedom and will, regardless of the other. Thus, there are symptoms of decreased tolerance. Political and social fragmentation continues, especially among the political, social, and military elites, which continue to infiltrate the grassroots and lead to horizontal conflicts that are latent and widespread. There are various indications, conflicts and religious nuances, even in the provocations of the certain elites for their own interests. The inconsistency of law enforcement also matters. Some cases of religious conflict or violence or carrying religious symbolism show indications of conflict between security forces, and even contestation among local elite groups. Finally, the widespread disorientation and dislocation in Indonesian society, due to difficulties in daily life, is also a proof of the emergence of religious radicalism movements. The increase in the price of other daily necessities makes the society increasingly pressured and marginalized. As a result, these marginalized and splintered people or groups can easily carry out emotional acts, and can even be hired to commit unlawful acts and violence. ${ }^{15}$

${ }^{14}$ Khamami Zada, Islam Radikal; Pergulatan OrmasOrmas Islam Garis Keras di Indonesia (Jakarta: Teraju, 2002), 95. Samuel Huntington (1997) with a Clash of Civilization thesis that sees terrorism as an implication of the clash of two major civilizations in the world: Islam vis-a-vis the West. Huntington's logic stems from a realistic viewpoint that views world politics as a struggle for power --a power struggle. Huntington departs from the division of the world over what he calls "civilization." Huntington regards the world as a multipolar mix of civilizations, thereby dividing the world into eight major civilizations. The principle of realism that positions interest in the context of power member the second logical basis: competition between civilizations generate conflict. If that logic is used as a tool to interpret radicalism in Indonesia, we will come to a point of conclusion: terrorism is the excess of the incompatibility of Islamic civilization and the West. This is reinforced by the attributes imposed by the perpetrators of terror, by giving the tint of Islam as an argument. See Ahmad Rizky Mardhatillah Umar, "Tracing the Roots of Radicalism in Indonesia", Journal of Social and Political Sciences, 14 (2) November 2010: 171

${ }^{15}$ Azyumardi Azra, "Akar radikalisme keagamaan peran aparat negara, pemimpin agama dan guru untuk kerukunan umat beragama", Paper presented at Discussion 'Reinforcing Tolerance Through Schools' at the Habibie Center, Hotel Aston, Bogor, 14 May 2011. Quoted Abdul Munip, Counteracting Religious Radicalism in Schools, Journal of Islamic Ed- 
Further explanation comes from Endang Turmudzi (2005). He argues that some factors leading to the emergence of radicalism include the variable of attitude or view of the three issues of application of Islamic Sharia, the form of Islamic state of Indonesia and the Islamic Caliphate. This attitude is a continuation of the interpretation of the teachings of Islam. It is assumed that there are some common attitudes that arise after society interprets Islamic teachings. This attitude is symbolized in the application of Muslim understanding of their religious teachings. In this case there are three groups: secular or relative, substantialist and scripturalist ${ }^{16}$. In addition, the variable of attitude that arises when the second variable is confronted with real social conditions in society. These include domestic and international factors. Political hegemony by the state or any repression by any group against Muslims will give rise to different responses from different groups. The secular do not respond because they are truly indifferent. Only the scripturalists are assumed to be radical. The substantial group, despite its concern for Islam and its people in various fields, will show moderation. For example they will look good on the Islamic state or Khilafah Islamiyah as well as on (formalization) the application of Islamic Sharia. ${ }^{17}$ According to Azra (2003), the emergence of radical groups in Indonesia is caused by the euphoria of democracy as well as the revocation of the Anti-Subversion Act by President Habibie which in turn provides widespread space for extremist groups to express ideas and activities. ${ }^{18}$ Abuza (2007) also mentions that the fall of Soeharto's authoritarian regime led to the massive birth of civil society forces which in turn provided space to certain groups including radical groups who expressed their interests by spreading hatred and intolerance by using violent means (violence). ${ }^{19}$

Discourse on radicalism and terrorism has been on the rise after the September 11, 2001. ${ }^{20}$ Based on the data, this work indicates that radicalism and terrorism in Indonesia are caused by two fundamental problems i.e., economic deprivation (poverty) and political injustice, as also supported

ucation UIN Sunan Kalijaga Graduate Program Vol 1. Number 2 December 2012, 162

${ }^{16}$ Endang Turmudi (ed), Islam dan Radikalisme di Indonesia, (Jakarta :LIPI Press, 2005), p. 2

${ }^{17}$ Endang Turmudi (ed), Islam dan Radikalisme di Indonesia, (Jakarta :LIPI Press, 2005), p.2

${ }^{18}$ Azyumardi Azra, 2003, Bali and Southeast Asian Islam: Debunking the Myths di Kumar Ramak rishna dan See Seng Tan (Editor), After Bali: the Threat of terrorism, Institute of Defence and Strategic Studies, Nanyang Technological University, Singapore

${ }^{19}$ Abuza, Zachary 2007, Political Islam and violence in Indonesia, Routledge, London and New York

${ }^{20}$ Khamami Zada, Islam Radikal; Pergulatan OrmasOrmas Islam Garis Keras diI ndonesia, (Jakarta: Teraju, 2002), p.17 
by research findings by Khamami Zada (2002). ${ }^{21}$ The labeling of radical to the group that has the character and the general pattern as a movement that demands the enforcement of Islamic Shariah in terminology as mentioned by Kallen (as quated by Umi Sumbulah, 2010). ${ }^{22}$ Radicalization emerges as a response in the form of evaluation, rejection or resistance to the ongoing conditions, whether it be the assumption of value or religious or state institutions. Radicalization always seek to replace the existing order with a new order systematized and constructed through their own world view. The strong belief in the ideology they offer is vulnerable to emerge a potential emotional attitude resulting in violence. In this context, Islamic mass organizations such as the Islamic Defenders Front (FPI), Hizbut Tahrir Indonesia (HTI), Majelis Mujahidin, Laskar Jihad Ahlussunnah Waljama'ah, Indonesian Committee for Islamic World Solidarity (KISDI) and Indonesian Islamic State (NII) have the features as described by Horace M. Kallen. They fight for Islam in a kaffah (totalistic); Islamic law as a state law, Islam as the basis of the state, as well as Islam as a political system so not a democracy that serves the voice of people's aspirations into a political system. They base their practice of religion on the past orientation (salafi). They are also very hostile to the West with all the products of civilization, such as secularization and modernization. And they resistance to the growing Islamic liberalism movement among Indonesian Muslims.

\section{RADICALISM IN THE ISLAMIC CONTEMPORARY ERA}

What is the radicalist or fundamentalist movement in Islam today, especially the contemporary era? It seems to be more influenced by the Islamic response to the West although the themes are related to inward orientation that becomes their concern and ideological choice. According to Azyumardi Azra (2016), contemporary fundamentalism and radicalism arise in reaction to the penetration of Western social, cultural, political and economic systems and values, both as a result of direct contact with the West and through Muslim thinkers. Strictly speaking, modernist, secularist, and Westernist groups or regimes of Muslim governments that fundamentalists argue are an extension of the Western ideas and control. ${ }^{23}$ There are at least two major problems of concern to this group. Firstly, they reject the secularism of Western societies

\footnotetext{
${ }^{21}$ Khamami Zada, Islam Radikal; Pergulatan OrmasOrmas Islam Garis Keras di Indonesia(Jakarta: Teraju, 2002), p.17

${ }^{22}$ Umi Sumbulah, Islam Radikal dan PlularismeAgama: Studi Kontruksi Sosial Aktivis Hizb al-Tahrir dan Majelis Mujahidin di Malang tentang Agama Kristen dan Yahudi, (Jakarta: BALITBANG RI, 2010), p.42

${ }^{23}$ Gerakan Radikalisme dalam Islam: Perspektif Historis 13 ADDIN, Vol. 10, No. 1, February 2016
} 
that separate religion and politics, church, and mosque from the state. The Western success of secularization is perceived as dangerous, because it can threaten Islam as a religion that not only deals with the hereafter but also the world. Secondly, many Muslims want their society to be governed in accordance with the Qur'an and Islamic Sharia as the rule of the state. ${ }^{24}$ Therefore, it is not surprising today that an underground movement that aspires to establish an Islamic caliphate with the themes of God's sovereignty, jihad, Islamic revolution, social justice, and so forth. The themes are oriented towards the past, especially the early generations of Islam as practiced by the Prophet Muhammad his companions. They assume that the Islamic society today is declining because it no longer carry out the teachings of its religion purely. Therefore the above agenda must be done to counter Western hegemony while imagining the glory of Islam.

During the New Order era, the state always suppressed what was identified as a radical movement. Radicalism was seen as the prime enemy and used as common enemy through various media transformation. Left or right radicalism is the same. Left radicalism such as the New Left movement, which had flourished in Indonesia around the 1980s and continued to gain momentum in the 1990s through the People's Democratic Party (PRD), was an exponent of an organization considered an enemy of the state. So strong was the pressure on this left radical movement that many of the members were arrested, tortured, and even some were gone without a trace. The New Order was very hard on right radicalism. Among the most prominent was the Komando Jihad in the mid-1980s. Many Islamic leaders were identified as leaders or members of the Komando Jihad who were arrested and imprisoned. Attempts to suppress these radical Islamic movements continued until the period of the rise of the Association of Indonesian Muslim Intellectuals (ICMI) in the mid-1990s.

Abdul Aziz Thaba (1995) finds a connection between Islam and the State in three categories including the relationship between Islam and the State, which is antagonistic, critical reciprocal, and the symbiotic relationship between Islam and the State. An antagonistic relationship occurred at the beginning of the New Order ${ }^{25}$ until the early 1980s and symbiotic relations occurred in the era of the 1990s. Several groups called Islamic militant groups in Indonesia were formed in conjunction with national political events, while others were

${ }^{24}$ See Karen Amstrong, Berperang Demi Tuhan: Fundamentalisme dalam Islam, Kristen dan Yahudi (Jakarta: Serambi, 2001), p. ix. See also Leonard Binder, Islamic Liberalism: a Critique of Development Ideologies (Chicago and London: The University of Chicago Pres, 1988), p. 16-49.

${ }^{25}$ Abdul Aziz Thaba. (Islam dan Negara dalam Politik Orde Baru. ( Jakarta: Gema Insani Press. 1995). p. 37 
a reaction to events related to conflict between Muslims and Christians occurring in some areas. Each organization has its own background and raison detere as well as differences and similarities, including: FPI (Islamic Defenders Front), FKA WJ (Communication Forum of Ahlussunnah wal Jamaah) and MMI (Indonesia Mujahidin Council). ${ }^{26}$

An example in the Indonesian cases of contemporary radical Islamic movements that can be mentioned here is Hizbut Tahrir Indonesia (HTI). ${ }^{27}$

${ }^{26}$ This movement case is related to the rise of BJ. Habibie as the president, after President Soeharto resigned, because Habibi was considered part of the new order, students demanded a demonstration for the replacement of the new leader, to compensate for the great powers of the students, the TNI recruited Pam Swakarsa from various regions (Banten, Central Java and other), Pam Swakarsa is the forerunner of FPI. FPI was formed in Jakarta, at the Pesantren Al-Umm Ciputat leader of kyai. Misbahul Anam, as a pressure group movement aimed at eradicating prostitution, night house entertainment, led by a young preacher, Habib Riziq Shihab. And the public attention, because the action did not hesitate to eliminate disobedience by using violence. While FKAWJ (Communication Forum Ahlussunnah Wal Jamaah) genealogy is closely linked to the Jamaah al-Turath al-Islami in Jogjakarta, a movement founded by Ja'far and Abu Nida (Chamsaha Shofwan), FKAWJ was declared on 14 February 21999. For the services of M. Umar As-Sewed, Ayif Syarifudin and Maruf Bahrun. This group is a "semi clandestine" movement, because they prefer to hold meetings in secret. No wonder the group is associated with the Muslim Brotherhood and DI/TII movements. The birth of FKAWJ was motivated by the economic, political and social crisis that plagued Indonesia since the Reformation, FKAWJ with its military wing Laskar Jihad joined the umta Islam forum during the Habibie administration. Third, MMI (Majleis Mujahidin Indonesia, declared in August 2000 in Yogyakarta attended by thousands of Moslems from domestic and abroad and elected as Amir MMI was Abu Bakar Ba'asir. This aesthetic appeals to Abu Bakar Ba's relationship with the Jihad command movement together with Abdullah Sungkar, the founder of Ngeruki pesantren. Majda's main agenda is to enforce Islamic law, MMI chooses political and academic paths, so often differing opinion with FPI and Laskar Jihad. HMI is also regarded as an extension of the Southeast Asian Islamiyah organization that wants to destroy Western and South American facilities in Southeast Asia In addition to the Movements, there are three other hardline Islamic militant groups, Darul Islam, Hizbut Tahrir, Tarbiyah Islamiyah and Muslim Brotherhood, although the similarities are found in the application of Islamic Sharia, but each has group agenda which sometimes becomes a very sharp distinction. (See Bachtiar Efeendi, Sutrisno Hado, Agama dan Radikalisme di Indonesia, Jakarta: Nuqtah, 2007), p.13-18

${ }^{27}$ HTI launched its movement gradually. In the case of Indonesia, there is no strong evidence to show HTI's involvement in acts of violence and terrorism. Therefore, it is important to understand the activity and its relation to jihad action. There are three stages or three steps HTI in an effort to achieve its political goals, namely: (a) Stage Tatsqif (coaching and cadre). This stage is to give birth to people who believe in Hizb ut-Tahrir and to form the framework of a party. (b) Tafa'ul Stage (interaction), ie interacting with people to be able to carry Islamic da'wah, so that people will make it as the main problem in their life, and try to apply it in the reality of life. (c) Istilamul Hukmi's stage (takeover of power). This stage serves to apply Islamic law in practice and totality, as well as to spread to the whole world. These three stages are used by HTI in an attempt to achieve the goal of establishment of Islamic State. This indicates that the HTI struggle begins with bawap. It is therefore very active in the recruitment of members, the process of cadre- gation, and the dissemination of information through mass media, famphlets, seminars and street demonstrations as part of strategic steps to achieve the goal of establishing a caliphate See Hizbut Tahrir Organization, 
This organization is radical in its political ideas, but emphasizes peaceful ways to achieve its goals. Its radicalism is illustrated by the HTI struggle that seeks fundamental political change through the total destruction of the nation-state today, and replacing it with a new Islamic state under a caliphate. ${ }^{28}$ These three groups are just some of the other hard-core Islamists: Darul Islam, Hizbut Tahrir, Tarbiyah Islamiyah and Muslim Brotherhood, ${ }^{29}$ although it is clear that they have similarities in the application of Islamic law, but each has its own agenda which sometimes becomes a very sharp distinction. The existence of the group's agenda, which may be closely linked to political interests, makes such groups often cooperate with others with similar interests, but their similarities, as much as the differences prevent them from uniting in one group.

Based on their actions and movements, radical Islamic groups have made concrete efforts, both through the structural-vertical and cultural horizontal ways. They already have access to the parliament. They also directly enforce amar ma' ruf nahi munkar (promotion of virtues and prevention of vice), such as entering into the Poso Ambon conflict, the destruction of discotheques, brothels, supporting the ratification of Anti-Pornography Bill, expulsion of the Ahmadiyya group, and Christian congregation illegal churches, destruction of the editorial office of Playboy, etc. They also easily accuse the others of being infidels. ${ }^{30}$ To some extent, the action of radicalism is the result of the slow pace of the authorities in responding to the development of mass psychology. The violent acts perpetrated by radical Islamic groups have unconsciously revealed that Islam supports violent acts. But this radical Islamic group movement is not mainstream in Indonesia. LSI's research shows that FPI is only supported by $17 \%$, MMI $11 \%$ and HTI $3 \%$ of the Indonesian Islamic society. ${ }^{31}$

According to some research, most Australians do not know much about Islam in Indonesia. When asked whether Indonesian Muslims and Middle Eastern Muslims the same, their answer is that Indonesian Islam is more moderate and tolerant. When asked about the Bali bombing action, they say that it is a sign that radical Islam has developed in Indonesia. If radical Islamic action

The Methodology of Hizbut Tahrir for Change (London: al-Khilafah Publication, 1999), p. 32.Anzar Abdullah ADDIN, Vol. 10, No. 1, February 2016

${ }^{28}$ Karagiannis dan Clark Mc Cauley, "Hizbut Tahrir al-Islami: Evaluating the Threat Posed by a Radical Islamic Group that Remannis Non Violence", dalam Terrorism and Political Violence, No. 58 (2006), hlm. 318.Gerakan Radikalisme dalam Islam: Perspektif Historis ADDIN, Vol. 10, No. 1, Februari 2016

${ }^{29}$ Bachtiar Efendi, Sutrisno Hadi, Agama dan Radikalisme di Indonesia, Jakarta: Nuqtah, 2007), p.13-18

${ }^{30}$ Bachtiar Efeendi, Sutrisno Hadi, Agama dan Radikalisme di Indonesia, Jakarta: Nuqtah, 2007), p.237

${ }^{31}$ Saiful Mujani, ” Kelompok Islam Anarkis”, Media Indonesia, 12 June 2006 
does not diminish in Indonesia, the negative image of Indonesian Islam in the international world will spread. Given the factors causing the contradictions to their religion in such a complex way, everyone should be warned not to hurry to take a hasty conclusion, a kind of sweeping generalization. If there are certain people and / or religious groups committing violence in the name of religion, they are clearly not representation of religion or religious people as a whole.

\section{RELIGIOUS RADICALISM, JIHAD AND TERRORISM}

The facts show that there are deviations in understanding jihad that begins to be misused by a group of people who have a hard-line view of the teachings of Islam, thus legalizing violence in doing the action. The discourse of religious radicalism among Muslims, often using jihad terminology in its action, the fact that the terrorist network (as a radical act of action) behaves in the name of jihad (especially in Indonesia), is proof that this theological foundation is very effective in giving suggestions to everyone to do whatever it takes, as evidenced in several bombings (suicide bombings), which are identified as hard-line Islamic groups in Indonesia that have the motive of killing foreigners, especially citizens of the United States, Israel and its allies in Indonesia as the embodiment of jihad, as explained by Fahruroji Dahlan (2008). ${ }^{32}$ In the Qur'an the word Jihad, as explained by Ma'ruf Amin (2007) ${ }^{33}$, as a noun is often followed by the phrase fi sabîl Allah (in the way of Allah). Jihad if you want to establish the religion of Alah is indeed one of the teachings of the Qur'an which must be carried out by Muslims. For those who implement it will certainly get a good reward, because jihad activities are carried out the implementation of faith and obedience to the teachings of God. When he dies while carrying it out, he is called shahíd whose return is heaven. At this level, all the consequences of jihad that is done is not something that must be a burden, if successful, the teachings of God will be upright and it must have virtues and benefit to society, and if failed and he dies in the struggle, then the promise of God will still be good that is dying as a martyr and return to heaven. ${ }^{34}$ Seeing this phenomenon a lot of Muslims dare to risk their lives.

${ }^{32}$ Fahruroji Dahlan, "Jihad Antara Fenomena Dakwah dan Kekerasan Mereformulasikan Jihad Sebagai Sarana Dakwah", in El Hikmah Journal, Volume 1/No. I/December 2008/Dzulhijjah 1429 p.71

${ }^{33}$ K.P. Ma,ruf Amin. Melawan Terorisme Dengan Iman, (Ciputat: Tim Penanggulanagan Terorisme, 2007), p. 187

${ }^{34} \mathrm{Jihad}$ is etymologically an Arabic word that has been absorbed in the Indonesian language, its origin is juhd or jahd, that is, the first, to exert energy, effort, power, while the second meaning is sincerity in work. Thus the word Jihad is to exert energy and ability to do something with full sincerity. Besides the word jihâd also means war, but for the definition of this war, the Qur'an uses the other two words namely al-qitâl and al-harb. In the Qur'an, 
In order to determine the attitude properly and correctly, about the nature of jihad and al-istishad, it must be properly and proportionally considered, because not knowing it correctly can fall on the attitude of $a l$-irhab ${ }^{35}$, not jihad or al-istishad ${ }^{36}$.

In its development, the definition of jihad is often misinterpreted by the perpetrators of terrorism, such as using suicide bombs as its implementation. To radical groups, jihad is an obligation to fight physically against the unbelievers. Then from that sense comes the meaning of being a war between Islam and the United States and Jews, as well as in the case of Bali Bombers, Imam Samudra and other groups, they hold that Jews and Christians are the ones who wish to destroy Islam which are represented by The United States and Israel. In their view, in jihad the only way to implement Islam is by destroying the United States, Israel and its allies. ${ }^{37}$ In this regard, the Indonesian Council of Ulama releases its fatwa on terrorism by distinguishing between the character of terrorism and jihad. Characteristics of terrorism include destructive (ifsad) and anarchist (faudha), the goal is to create fear and or destroy others, performed without rules and the goals are without limit. While the characteristics of jihad include nature requirement of the improvement (islah) and even with the way of war as needed, having the purposes of to uphold the religion of Allah and or to defend the rights of the oppressed and conducted by following the rules set by the Sharia with clear enemy targets. Therefore, if any religious radicalism which in its implementation may occur in a form of terrorism, one of the reasons is to use improper method in understanding religious texts and erroneous in its application. Hence, to

al-Qitâl is mentioned 13 times and in all derivations 144 times .. besides that there is also a word gazwah which means war joined by the Prophet, while also there is the word sariyyah, meaning the war between the Muslims and the infidels in the period of Prophet Muhammad SAW. But the Prophet did not take part in that war. The word Ghazwah is not mentioned in the Qur'an, except the word derivation which is guzzan mentioned once in the Qur'an. (QSAl-Imran: 156) .. Terminologically the meaning of Jihad has various meanings, according to Ar-Raghib al -Asfahani, jihad is a serious fight against the enemy to uphold the Religion of Allah or against the satan that always leads to the emergence of evil or against lust. Meanwhile, according to Ibn al-Qayim al-Jawziyya, Jihad is, struggling against lust, fighting satan, fighting infidels, and against hypocrites. (See K.P.Ma,ruf Amin. Melawan Terorisme Dengan Iman, Ciputat: Tim Penanggulanagan Terorisme, 2007), p. 188-189

${ }^{35}$ Al-Irhâb artinya terorisme (Lihat K.P.Ma,ruf Amin. Melawan Terorisme Dengan Iman, Ciputat: Tim Penanggulanagan Terorisme, 2007), p. 204

${ }^{36}$ In the word istishâd is a masdar from istashada-yastashidu which means to seek martyrdom, i.e. martyrs when upholding the teachings of Allah. The origin of the word is Syahida-yashadu, which means witnessing. Shahid, the Plural form of Shuhada can be interpreted as a witness or fallen person for defending the religion of Allah. (See K.P.Ma'ruf Amin. Melawan Terorisme Dengan Iman, Ciputat: Tim Penanggulanagan Terorisme, 2007), p. 204

${ }^{37}$ Sarlito W.Sarwono, Terorisme Di Indonesia Dalam Tinjauan Psikologiss, (Jakarta: Alvabert, 2012), p. 10 
avoid any misconduct, every Muslim needs to understand the Qur'an and the Hadith of the Prophet by starting using the correct method of understanding, then they should apply that understanding correctly. ${ }^{38}$

Jihad, according to Azyumardi Azra (1999), is often identified by many scholars, both non-Muslim and Muslim with holy war, understood as war against the unbelievers. But as Peters puts it, the main purpose of jihad is not to force people to enter Islam, put forward in Western literature. The aim is essentially for expansion as well as defense of the Islamic region (Dar alIslam). ${ }^{39}$ Similar opinion is also held by Watt, although the reasons given are quite different and even need to be questioned. According to Watt, the jihad terminology with holy war is misleading. Jihad for the expansion of Islamic territory occurred in the classical period, it is a further development of "razzia "(Ghazwah's military expedition). In this motive, the expansion of religion is not the primary, the acquisition of booty is the goal of the Muslim army. Watt's argument is, to some extent, true but the central weakness of this argument is that it reduces religion through a materialistic approach. ${ }^{40}$ According to $\mathrm{Al}$ Mawdudi ${ }^{41}$ Western writers have likened the word jihad to "holy war" until finally Jihad became a synonym of war based on religious fanaticism. AlMawdudi affirmed that Islam is not as sacred as the word's meaning, which seems to indicate the concept that belief is a personal affair no more than a set of customs and standardized worship procedures. This is due to two mistakes in understanding the word jihad, which is to understand it as a war or fanaticism for the purpose of spreading religion. ${ }^{42}$

Nazaruddin Umar distinguished the meaning of jihad in exoteric and esoteric manner. Exoteric is usually interpreted as holy war, while esoteric jihad as a serious effort to get closer to Allah Almighty. Jihad in the sense of holy war by some experts is seen as a definition that is influenced by the Christian concept (Crusade). Thus the meaning of jihad is different from the qital meaning (including the harb) which has different meanings in the Qur'an and the

\footnotetext{
${ }^{38}$ Majelis Ulama Indonesia, Fatwa of the Indonesian Council of Ulemas on Terrorism, the Leadership of Indonesian Council of Ulemas, Jakarta, 2005, p. 9

${ }^{39}$ Azyumardi Azra, Pergolakan Politik Islam (Bandung: Mizan, 1999), p. 128

${ }^{40}$ Azyumardi Azra, Pergolakan Politik Islam (Bandung: Mizan, 1999), p. 129

${ }^{41}$ Jihâd is basically the struggle of the Muslims to realize the ideals that they always strive. Al-Mawdudi also divides jihad into two types: for defense and for corrective or reformative purposes. The first type of Jihâd is the war to protect Islam and its followers from the enemy attack or destruction of Dâr al-Islâm. While the second can be aimed at anyone who causes tyranny to the Muslims who live in their land, Azyumardi Azra, Transformasi Politik Islam, (Radikalisme, Khilafatisme, dan demokrasi), (Jakarta: Prenadamedia Group, 2016), p. 172

${ }^{42}$ Azyumardi Azra, Transformasi Politik Islam, (Radikalisme, Khilafatisme, dan demokrasi), (Jakarta: Prenadamedia Group, 2016), p. 169-170
} 
Hadith. Al-Qital and al Harb are both associated with war. The Qur'an when speaking of war commands is very cautious. And even if there is a verse that commands war, it is in order to defend against the intrusion and persecution of outsiders. As explained in the Qur'an of Surah Al-Baqarah (2) verses 190$194 .^{43}$

Justification of jihad with terrorism in the present day is due to the fact that jihad in the sense of war involves elements of violence that can be categorized as terrorism. But clearly the use of violence in the name of religion in the contemporary era is actually due to political factors, which then seeks legitimacy in religious teachings. The people of Indonesia and the international community are currently faced with a very worrying situation due to the rampant acts of terror. Indonesia has suffered losses due to acts of terror, because it has caused the loss of lives of Indonesian citizens and foreigners, as well as loss of property and worsened the economy due to a prolonged crisis. The series of terror bombs in Indonesia, started in Legian Bali in October 2002, followed by the bombing at the Marriot Hotel Jakarta in 2003, in front of the Australian Embassy in Jakarta on 9 September 2004, the Bali Bombings II in 2005, and other bomb blasts tragedies. The bombings reflect a new form of violence and terror in the country. This not only resulted in relatively large number of victims, but also the use of deadly weapons by terrorists that have a greater psychological impact on national and international scales. Even worse, the terrorists use suicide bombers. In general, such bombings are very difficult to comprehend among Indonesians; it is cruel and inhumane. ${ }^{44}$

Terrorism ${ }^{45}$ is a view that argues that using violent means of fear is a legitimate means of achieving the goal. ${ }^{46}$ Thus, according to Nasir Abbas terror is an evil reaction considered "more evil" by the perpetrator, so it is not an

${ }^{43}$ Nazaruddin Umar, (dalam buku Jihad, Gamal Al-Banna), Jakarta: Mata air Publishing, 2006), p. vi-viii

${ }^{44}$ Azyumardi Azra, Islam Politik Radikal di Indonesia : Akar Ideologi Terorisme, Makalah disampaikan pada Diskusi Kajian tentang Terorisme di Ditjenstrahan Kemhan tanggal 16 Januari 2012, p. 14-15.

${ }^{45}$ In the dictionary of espionage, terrorism is defined as: "the unlawful use of force or violence to intimidate, coerce, fight and even kill people, community members, government, for political or other purposes." Indian National Security Guard, Act 1986, as follows: "Terrorists are groups / individuals who have a specific intention to attack the government or law enforcement by terrorizing people or parts of the community by engaging in actions and activities using equipment, bombs, dynamite, explosives, chemicals, combustible substances, toxins, harmful gases, other substances (biological and otherwise) that may pose risks to nature and the environment, which may be the cause, or may cause harm to injure or even kill many people, individuals or destructive, destroying property, possessions or can be menimb combat chaos and disrupt government or community life (See Henry S.A. Becket, The Dictionary of Espionage, New York : Stein and Day Publisher, 1986, p. 182.

${ }^{46}$ Muchamad Ali Syafa'at, Tindak Pidana Teror Belenggu Baru bagi Kebebasan dalam “terrorism, definisi, aksidan regulasi”, Jakarta : Imparsial, 2003, p. 59. 
interactionism and can be classified into evil vengeance (hate crimes). ${ }^{47}$ The term terrorist according to counterterrorism experts refers to perpetrators who are not incorporated in the armed forces or disobedient to the rules of the armed forces. Terrorist acts also mean that terrorist attacks are inhumane and have no justification, and therefore the perpetrators (terrorists) deserve cruel reprisals. Due to the negative meanings contained by the words "terrorist" and "terrorism", terrorists generally refer to themselves as separatists, freedom fighters, crusaders and militants. The true meaning of jihad is far from acts of terrorism that attack civilians who are not involved in war. Terrorism itself often appears in the name of religion. ${ }^{48}$

At first terrorism was categorized as a crime against the state but gradually developed into crimes against humanity. Terrorism has various characteristics, one of which is the spirit of religious radicalism. Religious radical groups are suspected of using terror methods to achieve their interests. Political violence in the form of terror is often used as a tool to achieve goals. Islamic jihad groups in Egypt, Islamic jihad in Yemen, the National Islamic Front in Sudan, the Afghanistan-based Al-Qaeda, the Jemaah Islamiyah based in Malaysia or radical Jewish groups such as Haredi, Bush Emunim, Kach Kaheni in Israel are simply examples elements with the spirit of religious radicalism that tends to promote violence and terror. ${ }^{49}$ Regarding acts of terrorism in Indonesia, during the year 2000-2009 it was recorded that the have been 23 bombings, both on a small scale and large scale. Started with the Philippine Embassy bomb, August 1,2000 . The bomb exploded from a car parked in front of the residence of the Philippine Ambassador in Menteng, Central Jakarta. Two people were killed and 21 others wounded, including Philippine Ambassador Leonides T. Caday. In 2009, the Jakarta bombing, the terrorists blasted JW Marriott Hotel and Ritz-Carlton Hotel in Mega Kuningan on Friday morning, July 17, 2009 with 9 people killed and 55 injured. However, terrorist acts in Indonesia actually started with a bomb explosion that occurred in the Complex of Cikini College in an effort to assassinate the First President of Indonesia Ir. Soekarno, in 1962 and continued in the following years until August 2001, at Plaza Atrium, Senen, Jakarta. The explosion wounded six people, all bombings in Indonesia from 1962 to August 2001 only became domestic issues, but since the World Trade Center (WTC) incident in New York, USA on September 11, 2001,

\footnotetext{
${ }^{47}$ Nasir Abas, Kajian tentang Terorisme, Paper presented at Discussion on Terrorism Studies at Directorate General of Defense Strategy of the Defense Ministry on 16 January 2012, p. 1.

${ }^{48}$ Publikasi,umy.ac.id/index.php/hi/article,kajian_terorisme.p. 2-3

${ }^{49}$ Luqman Hakim, Terorisme Indonesia, Forum Studi Islam, Surakarta: Surakarta (FSIS), 2004, p. 19
} 
which claimed 3,000 victims, the issue of terrorism has become global. ${ }^{50}$

The events of September 11, 2001 initiated a new round of terrorism into a global issue affecting the political policies of all countries in the world, thus becoming the starting point of perception to fight terrorism as an international enemy. The mass killings have united the world against international terrorism. Terrorism crime is a form of international dimension of crime that is very scary. In many countries of the world there have been terrorism crimes in both developed and developing countries. The acts of terror committed have taken their victims indiscriminately. This led the United Nations in its congress in Vienna Austria in 2000 to address the theme of Prevention of Crime and Treatment of Offenders, including the mention of terrorism as a development of violence that needs special attention. According to Muladi (2004), terrorism is an extraordinary crime which requires handling by utilizing extraordinary measures because of various things. ${ }^{51}$

Lukman Hakim (2004) mentions that terrorism is the act that creates the greatest danger to human rights, in this case, the right to life and the right to be free from fear. The target of terrorism is random or indiscriminate that tends to sacrifice innocent people. It has the possibility of using weapons of mass destruction by utilizing modern technology. It has also the tendency of negative synergy between national terrorist organizations and international organizations. There are possiblelities of cooperation between terrorist organizations and organized crime both national and transnational. It is also jeopardizing international peace and security. Terrorism as a crime has evolved into cross-country. ${ }^{52}$ Crimes occurring within a country are no longer merely seen as the jurisdiction of one country but can be claimed to include jurisdiction over more than one country. According to Romli Atmasasmita (2000), in its development it can lead to conflict of jurisdiction that can disrupt international relations between countries concerned in handling cases of dangerous crimes that are cross-border. Terrorism crime uses one form of transnational crime that threatens the peace the world..$^{53}$

\footnotetext{
${ }^{50}$ Ardison Muhammad, Terorisme Ideologi Penebar Ketakutan, Surabaya : 2010, p. 23.

${ }^{51}$ Muladi, Penanggulangan Terorisme Sebagai Tindak Pidana Khusus, paper of the Seminar on the Safeguard of Terrorism as Special Crime, Jakarta : 28 Januari 2004.

${ }^{52}$ Luqman Hakim, Terorisme Indonesia, Forum Studi Islam, Surakarta : (FSIS), 2004), p. 19.

${ }^{53}$ Romli Atmasasmita, Pengantar Hukum Pidana Internasional, Bandung : PT. Rafika Aditama, 2000, p. 58. Walter Laqueur, who spent his life investigating the phenomenon of terrorism, expressed the difficulty of defining precisely. He argues that, Terrorism cannot be classified as a war because it differs from war. In addition, also outside the field of guerrilla warfare, war aims for total destruction. Conventional war is a revolutionary war to inflict physical damage. While terrorism tends to inflict psychological damage. Terrorism is often regarded as a guerrilla action or one of the ways that does not adhere to the principle of guer-
} 
I would argue here that fundamentalism and radicalism in Islam as well as in other religions, have characteristics that distinguish it from other groups. As Martin E. Marty (1992) mentions, fundamentalism includes scripturalism, the literal belief in scripture that is the word of God, that is considered to be true. The case of the rejection of hermeneutics. The Qur'anic texts in the view of this group should be understood literally as they read. Reason is deemed incapable of giving a proper interpretation of the text, even to the contradictory text of each other. The rejection of pluralism and relativism is considered to undermine the sanctity of the text. The rejection of sociological/ historical development is considered to bring humanity farther from the literal doctrine of scripture. The monopoly of truth over religious interpretation becomes a mainstream. Radical fundamentalists tend to regard themselves as the most valid and legitimate interpreters, so they tend to disregard other groups that are different from them..$^{54}$ As quited by Muhammad Mubarrak (2008), Mohammed Arkoun sees Islamic fundamentalism as two opposite attractions, namely, ideological and political issues. And, Islam will always be in the middle. people do not always understand the truth about the case, that fundamentalism is randomly understood in the substantive part of Islamic teachings while political and ideological phenomena are neglected. ${ }^{55}$

Understanding Islam is an activity of consciousness that encompasses historical, social and political contexts. It is also the case in understanding the development of Islamic fundamentalism. Political and social attraction has created ideological structure in the human mind. In fact, Islam never offers violence or radicalism. The issue of radicalism has been merely the commotion of power that has grown in acute fanaticism. In its history, radicalism was born out of social and political crosses. Islamic radicalism in Indonesia is a reality of opposite attraction.

\section{CONCLUSION}

Religious radicalism is a common phenomenon that arises in any religion. The rise of religious radicalism has its roots in the reality of various interpretations, ideas, schools of thought, denominations, and even sects within one particular religion. In the case of Islam, religious radicalism stems

rilla itself. In action, murder, kidnapping, rioting, campaigning and other acts always ignore all forms of war rules and procedures. Victims in a terrorist act are mostly people who at the time of the incident are near or together with the targeted victims (see Adhie S, Terorisme, Jakarta: Pustaka Sinar Harapan, 2005, p. 10.

${ }^{54}$ Martin E. Marty, "What is Fundamentalisme? Theological Perspective", in Hans Kun dan Jurgen Moltmann (eds.), Fundamentalism as a Cumanical Challenge (London: Mac Millan, 1992), p. 3-13.

${ }^{55}$ Mubarak, Muhammad, Geneologi Islam Radikal di Indonesia, Jakarta: LP3ES, 2008 
from literal, piecemeal and ad hoc religious understanding of Qur'anic verses (interpretation of the meaning of jihad). Such an understanding can hardly provide space to accommodate and compromise with other moderate Muslim groups. In addition, there are several factors supporting radicalism and terrorism both internal and external factors, namely the continuation of social conflicts between and inside religions in this period of reform, due to various factors that are very complex. The first is related to the euphoria of freedom, in which each a person or group feels able to express their freedom and will. Secondly, political and social fragmentation continues, especially among political, social, and military elites, which continue to have impact on the grassroots and lead to horizontal and latent conflicts. There have been various indications, conflicts and religious nuances even the provocation of certain elites for their own interests. Third, the inconsistency of law enforcement. Fourth, widespread disorientation and dislocation in Indonesian society, due to difficulties in daily life.

It is necessary to reconstruct the paradigm of both Muslims and the West with regards to religious radicalism. The West, for example, must be willing to change they way they look at Muslims, not opposing Muslims, but treat them as equal partners to build civilization. For Muslims, they do reconstruct the definition of jihad in a more progressive direction, which is not only understood to be limited to Qitâl (war) physically, but the broader meaning of jihad (including, among other, jihad in the fight against lust, in study, in worship and in work).

\section{BIBLIOGRAPHY}

Abas, N. (2012). "Kajian tentang Terorisme”, paper presented at Diskusi Kajian tantang Terorisme. Ditjenstarahan Kemhan on 16 Januari 2012.

Ali, M. S. (2003). “Tindak Pidana Teror Belenggu Baru bagi Kebebasan” in Terrorism, definisi, aksidan regulasi. Jakarta : Imparsial.

Amstrong, K. (2001). Berperang Demi Tuhan: Fundamentalisme dalam Islam, Kristen dan Yahudi. Jakarta: Serambi.

Atmasasmita, R. (2000). Hukum Pidana Internasional. Bandung :PT. Rafika Aditama.

Aziz, A. T. (1995). Islam dan Negara dalam Politik Orde Baru. Jakarta: Gema Insani Press.

Azra, A. (2015). Waspadai Paham Radikal, KOMPAS, 7 April 2015. 
(2003). "Bali and Southeast Asian Islam: Debunking the Myths" in Kumar Ramak Rishna dan See Seng Tan (Ed.). After Bali: the Threat of Terrorism, Institute of Defence and Strategic Studies. Singapore: Nanyang Technological University.

. (2012). "Islam Politik Radikal di Indonesia : Akar Ideologi Terorisme." Paper presented at Diskusi Kajian tentang Terorisme. Ditjenstrahan Kemhan on 16 Januari 2012.

------. (2016). Transformasi Politik Islam, (Radikalisme, Khilafatisme, dan Demokrasi). Jakarta: PRENADAMEDIA GROUP.

(1999). Pergolakan Politik Islam. Bandung: Mizan.

(1996). Pergolakan Politik Islam, dari Fundamentalisme, Modernisme Hingga post-Modernisme. Jakarta: Paramadina.

(2011). "Akar Radikalisme Keagamaan, Peran Aparat Negara, Pemimpin Agama dan Guru untuk Kerukunan Umat Beragama." Paper presented at Diskusi 'Memperkuat Toleransi Melalui Sekolah. Bogor: The Habibie Centeron 14 Mei 2011.

Binder, L. (1988). Islamic Liberalism: a Critique of Development Ideologies. Chicago and London: The University of Chicago Press.

Dahlan, F. (2008). "Jihad Antara Fenomena Dakwah dan Kekerasan Mereformulasikan Jihad Sebagai Sarana Dakwah." in Jurnal El Hikmah, Vol 1/ No. I/Desember 2008/Dzulhijjah 1429 H.

Martin, M. E. (1992). "What is Fundamentalisme? Theological Perspective." in Hans Kun dan Jurgen Moltmann (eds.), Fundamentalism as a Cumanical Challenge. London: Mac Millan.

Efendi, B. \& Hadi, S. (2007). Agama dan Radikalisme di Indonesia, Jakarta: Nuqtah.

Gholib, A. (2016). Teologi dalam Perspektif Islam, Jakarta: UIN Jakarta Press.

Haitami, M. S. (2016). Islam dan Persfektif Tentang Radikalisme Agama, http:// www.pascapontianak.com. Diakses tanggal 9 Oktober 2016.

Hakim, L. (2004). Terorisme Indonesia, Forum Studi Islam, Surakarta : Surakarta (FSIS).

Harfin, M. Z. (2010). "Fundamentalisme dan Upaya Deradikalisasi Ayat al Quran dan Hadis.” dalam Jurnal Religia, Vol. 13, No. 1, April 2010.

Hornby, A. (1989). Oxford Advanced Learner Dictionary of Current English. Walton: Oxford University Pers. 
Hizbut Tahrir Organization, The Methodology of Hizbut Tahrir for Change (London: al-Khilafah Publikation, 1999), h. 32.Anzar Abdullah 12 ADDIN, Vol. 10, No. 1, Februari 2016

Jurgensmever, M. (2002) Teror in The Mind of God: The Global Rise of Religion Violence. (translated by M. Sadat Ismail). Jakarta: Nizham Press.

Karagiannis \& Cauley, M.C (2006). "Hizbut Tahrir al-Islami: Evaluating the Threat Posed by a Radical Islamic Group that Remannis Non Violence." in Terrorism and Political Violence. No. 58.

Ma 'ruf, A. (2007). Melawan Terorisme Dengan Iman. Ciputat: Tim Penanggulangan Terorisme.

Madjid, N. (1995). Pintu-Pintu Menuju Tuhan. Jakarta: Paramadina.

Majelis Ulama Indonesia, (2005). Fatwa Majlis Ulama Indonesia tentag Terorisme. Jakarta: Pimpinan Majleis Ulama Indonesia.

Montgomeri, W. W. (1992). Islamic Fundamentalism and Modernity, London: TJ. Pres. (Pradetshow).

Mubarak, M. (2008). Geneologi Islam Radikal di Indonesia. Jakarta :LP3ES.

Muhammad, A. (2010). Terorisme Ideologi Penebar Ketakutan, Surabaya.

Mujani, S. (2006). Kelompok Islam Anarkis. Media Indonesia. 12 Juni 2006.

Muladi, (2004). "Penanggulangan Terorisme Sebagai Tindak Pidana Khusus." Paper presented at Seminar Penanganan Terorisme sebagai Tindak Pidana Khusus, Jakarta : 28 Januari 2004.

Munip, A. (2012). 'Menangkal Radikalisme Agama di Sekolah.” Jurnal Pendidikan Islam. Vol 1. Nomor 2 Desember 2012.

Nasution, H. (1995). Islam Rasional. Bandung: Mizan.

Qardhawi, Y. (2001). Al-Sahwah al-Islamiyyah: Baina al-Juhad wa al-Tatarruf. Kairo: Bank at-Taqwa.

Rizky, A. \& Umar, M. (2010). "Melacak Akar Radikalisme di Indonesia." Jurnal Ilmu Sosial dan Ilmu Politik, 14 (2) November 2010

S, A. (2005). Terorisme. Jakarta : Pustaka Sinar Harapan.

S. H. \& A. B. (1986). The Dictionary of Espionage. New York: Stein and Day Publisher.

Sumbulah, U. (2010). Islam Radikal dan Plularisme Agama: Studi Kontruksi Sosial Aktivis Hizb al-Tahrir dan Majelis Mujahidin di Malang tentang Agama Kristen dan Yahudi. Jakarta: BALITBANG RI. 
Syam, N. (2001). "Radikalisme dan Masa Depan Agama;Rekontruksi Tafsir Sosial Agama.” Surabaya: IAIN Press.

Tahido, Huzaimah, Yanggo. (1997). Perbandingan Mazhab, Jakarta: Logos.

Turmudi, E. (ed). (2005). Islam dan Radikalisme di Indonesia. Jakarta :LIPI Press.

Umar, N. (2006). Jihad, Gamal Al-Banna. Jakarta: Mata air Publishing.

Wiryawan, S. S. (2012). Terorisme Di Indonesia Dalam Tinjauan Psikologiss, Jakarta: Alvabert.

Yani, Eka, Arfina, (?). Kamus Lengkap Bahasa Indonesia Dilengkapi Dengan EYD dan Singkatan Umum. Surabaya: Tiga Dua.

Zachary, A. (2007). Political Islam and Violence in Indonesia. London and New York: Routledge.

Zada, K. (2002). Islam Radikal: Pergulatan Ormas- Ormas Islam Garis Keras di Indonesia. Jakarta: Teraju. 
